\title{
Opportunity and Achievement in Northwest Iowa, 1860-1900
}

\section{William Silag}

UPON HIS RETIREMENT in 1900, Sioux City attorney Constant R. Marks began to compile material for a history of his community's pioneer generation. Marks did not count himself among that distinguished company, for his arrival in 1868 followed the pioneers by more than a decade. The people who interested Marks were those who took part in the land rush that brought hundreds of young men in search of new homes to the upper Missouri in the 1850s. Several dozen of them still lived in Sioux City nearly a half-century later, and they provided Marks with an unusually rich source of information about life in the old steamboat town. Marks devoted several years to collecting their reminiscences, which he edited and published in 1906 in a volume that can be termed a collective biography of Sioux City's founding fathers. ${ }^{1}$

As one might expect in a book of its kind, Marks's history is given to a mawkish filiopietism. Like other local histories of the era, Marks offers fulsome testimonials to the courage and vision of the pioneers. Nevertheless, the book does provide an unusually candid portrait of the land speculators and town boomers of the Civil War era. Marks quotes his subjects at length, and the pioneers' own accounts of the early years are marked by blunt honesty about the pecuniary motives that guided them. In the founders' own eyes, migration to the upper

1. C. R. Marks, Past and Present of Sioux City and Woodbury County (Chicago, 1904). The notes used by Marks to prepare this volume for publication are available on microfilm at the University of Iowa Libraries, where they are catalogued under the title, "Reminiscences of Sioux City Pioneers," C. R. Marks, comp., Marks Collection.

THE ANNALS OF IOWA 50 (Fall 1990). (C) The State Historical Society of Iowa, 1990. 
Missouri was motivated by a search for fortune. From the start, their stake in frontier Sioux City was chiefly material, and this common pursuit of personal ambition seems to have produced all there was of a social consensus in the antebellum community. Like pioneer Horace Bates, most of the old settlers reported to Marks that they had come west "looking for an opening in life" and remained in Sioux City only when convinced that they could do no better for themselves elsewhere than they could here. ${ }^{2}$

It appears they chose well. Marks tells how scores of pioneer capitalists, such as meatpacker James Booge and banker George Weare, amassed fortunes through business enterprises aimed at organizing the upper Missouri market. Local politicians did nicely too. The business of government on the frontier of American agriculture created excellent personal opportunities for appointed officials such as Samuel Yeomans, William Smith, and others attached to the United States District Land Office in the years before 1880 . Once established in the frontier land market, Yeomans and Smith retained preeminent positions in the regional real estate trade for decades.

Together these frontier businessmen and politicians constituted the nucleus of an entrepreneurial elite that dominated the community's economic affairs through the late nineteenth century. Little wonder that they recalled Sioux City's past in terms of personal accomplishment: their own good fortune provided an impressive measure of community progress.

Neither Constant Marks nor the early settlers he interviewed had much to say about failure-about pioneers who for one reason or another were unable to turn to their own advantage the commercial development of the upper Missouri. Perhaps Marks's success stories held for Sioux City people in general; certainly his book conveys the sense of an industrious frontier community moving steadily toward regional prominence and prosperity. But one wonders. We know that the

2. The statement by Horace Gates is in Marks, "Reminiscences," Marks Collection. See also statements by other pioneer settlers here and in Marks, Sioux City and Woodbury County. For additional information about the pioneers, see an earlier county history compiled by A. W. Warner, History of the Counties of Woodbury and Plymouth, Iowa (Chicago, 1890-1891). 
financial panic of 1857 ruined many business enterprises in frontier Iowa, that a commercial slump in the mid-1870s slowed returns on investments in western land and transportation, and that a major national depression in the mid-1890s created profound problems for fledgling urban centers such as Sioux City as they approached the twentieth century. After all that, then, how typical of Sioux City's first half-century can Marks's success stories be?

One answer to that question is provided by population turnover rates, which measure the comings and goings of local populations. Men such as Booge and Weare belonged to a minority by the simple fact of their continued residence in Sioux City for nearly a half-century. Most of Sioux City's nineteenth-century population proved far less stable; no more than 35 percent of the men living in the town at any given moment could be found there ten years later. ${ }^{3}$ And what of those who remained? Did they.all enjoy personal success on a par with Booge and Weare? If not, did they make any material progress in the course of their careers in Sioux City?

Marks's history characterizes the upper Missouri as a place where opportunities abounded. Does this characterization apply only to the frontier era and the pioneer generation, or did chances for personal improvement continue to open throughout the years of Sioux City's development as a regional business center? And how about opportunities elsewhere in the upper Missouri region? Did men in hinterland towns and in the countryside experience social mobility to the same extent as workers in Sioux City? This essay tries to answer these questions by examining economic opportunity and individual achievement in northwest Iowa in the last four decades of the nineteenth century, beginning with a close look at the careers of the men who settled in Sioux City before the Civil War. ${ }^{4}$

3. William Silag, "Citizens and Strangers: Geographic Mobility in the Sioux City Region, 1860-1900," Great Plains Quarterly 2 (Summer 1982), 168-83.

4. Unfortunately, nineteenth-century data on personal wealth and occupations tell us very little about the economic experience of women. Based on my research to date, I can say very little about opportunity and achievement for women in northwest lowa in this period. At this point, my questions must be posed in terms of Sioux City's male population. Thus, did men's chances for personal improvement remain open throughout the period 1860-1900? 
THE ANTEBELLUM LAND BOOM lured thousands of people to frontier Sioux City, but the financial panic of 1857 sent most of its citizens packing. From a peak of two thousand persons in August 1857, the local population fell to approximately five hundred within a year. Except for annual infusions of transient deckhands and soldiers.on maneuvers, the community remained nearly the same size for the next ten years.

Throughout that decade, men aged 21 years and older made up about one-third of Sioux City's total population and virtually the whole of its labor force. Many operated businesses of one kind or another; in the spring of 1860,33 percent of the local men described themselves to federal census enumerators as merchants. In addition to bankers, realtors, and shopkeepers, Sioux City's steamboat economy also supported several dozen self-employed craftsmen and building tradesmen. Although the scale and income of most of the community's business firms were modest, a few establishments reported inventories or capital values in excess of five thousand dollars. Wholesalers Charles Booge and John Charles owned the largest enterprises, but lumber miller Luther Sanborn, grist miller Henry Roesch, and tinsmith E. W. Sinclair each operated plants valued at thirty-five hundred dollars or more. ${ }^{5}$

The owners of these prominent firms made up the top rank of Sioux City's nascent socioeconomic hierarchy. Realtorpolitician Ashbel Hubbard, who claimed personal assets of $\$ 30,000$, was the town's richest man in 1860 , while at least eight of his neighbors owned property worth $\$ 10,000$ or more. Land Office Register Samuel Yeomans reported \$16,000, dry goods dealer C. B. Hedges claimed $\$ 13,000$, and a lawyer, William Tripp, held $\$ 12,000$. With such relatively large concentrations of wealth held by a small elite, the mean personal wealth among Sioux City men on the eve of the Civil War was $\$ 2,065$, while the median was only $\$ 602$. These figures are slightly higher than those for the state of Iowa as a whole, where the mean was $\$ 1,517$ and the median $\$ 500$. Just nine-

5. Manuscript U.S. Census of Population, 1860. Unless otherwise noted, all data for this article come from Manuscript U.S. Census of Population, 1860, 1870, 1880, 1890, and 1900; and Manuscript Iowa State Census, 1885 and 1895. 


\section{TABLE 1}

Distribution OF WeALTH IN SiOUX CitY, ACCORDING TO ETHNIC GROUP, 1860 AND 1870

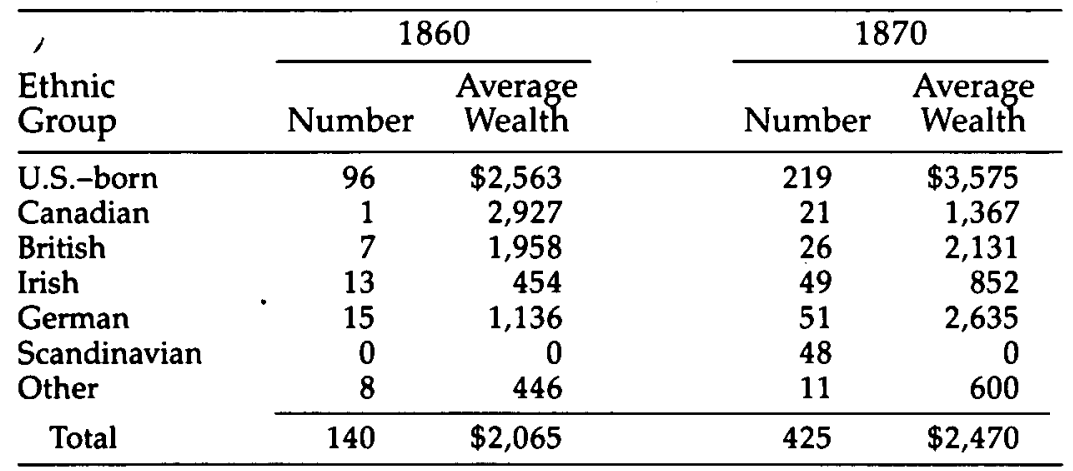

SOURCE: Manuscript U.S. Census, 1860, 1870.

teen Sioux Citians, representing 13 percent of the community's work force, owned no property at all in $1860 .^{6}$

Individual assets varied considerably among ethnic groups (see table 1). Men born in the United States reported property worth an average of $\$ 2,563$ in 1860 , well above the community mean of $\$ 2,065$. European immigrants, on the other hand, typically fell below that figure. Property holdings of native Englishmen averaged $\$ 1,958$, of Germans, $\$ 1,136$. The poorest of Sioux City's immigrants in 1860, Irish natives clustered at the bottom of the wealth scale. To some extent their position reflects their concentration in low-paying jobs (see table 2). While American- and German-born Sioux Citians could be found at all levels of the local occupational hierarchy before the Civil War, Irish immigrants tended to work as menial laborers or construction tradesmen. Men in these jobs were poorly paid to begin with and remained particularly susceptible to seasonal layoffs or occasional periods of inactivity throughout the year. Aside from printer William Freney and shoemaker Michael Gaughran, none of the local Irish natives held jobs that might be considered financially rewarding. ${ }^{7}$ By contrast, Sioux City's

6. Manuscript U.S. Census, 1860; figures for the state of Iowa calculated by Lee Soltow, in "The Economic Heritage of an Iowa County," Annals of Iowa 43 (Summer 1975), 26 (table 1).

7. In 1860 Sioux City's Irish immigrants were employed as follows: 7 day 
TABLE 2

OCCupational Distribution of Sioux City MEN, AGE 21 AND OLDER, ACCORDING TO ETHNIC GROUP, 1860

\begin{tabular}{lccc}
\hline $\begin{array}{l}\text { Ethnic } \\
\text { Group }\end{array}$ & $\begin{array}{c}\text { Professionals } \\
\text { and } \\
\text { Businessmen }\end{array}$ & $\begin{array}{c}\text { Clerks and } \\
\text { Craftsmen }\end{array}$ & $\begin{array}{c}\text { Menial and } \\
\text { Day Laborers }\end{array}$ \\
\hline U.S.-born & 51 & 27 & 15 \\
British & 0 & 3 & 4 \\
Irish & 1 & 4 & 8 \\
German & 7 & 6 & 2 \\
Other & 3 & 5 & 2 \\
$\quad$ Total & 62 & 45 & 31 \\
\hline
\end{tabular}

SOURCE: Manuscript U.S. Census, 1860.

Germans were prominent in the ranks of self-employed craftsmen and shopkeepers in 1860. Seven of the community's fifteen German natives (or 47 percent) worked as business or professional men, as compared with 55 percent of the U.S.-born men. Just one of Sioux City's thirteen Irishmen was similarly employed.

SIOUX CITIANS enjoyed a unique opportunity to turn accelerated commercial development to their own advantage in the late 1860 s. Completion of the Sioux City and Pacific Railroad in 1868 initiated expansion in all economic sectors, giving ambitious residents chances for material self-improvement unmatched since the boom years of the previous decade. Of course, many of the early settlers had already departed by then; fewer than half of the men residing in Sioux City in 1860 remained there ten years later. Ninety-four of 142 individuals, or 66.2 percent of the 1860 work force, had moved away or died by 1870 . Ethnic identity was not clearly related to residential persistence, but a pronounced tendency existed for men at the top of the local wealth scale to remain in Sioux City through the decade (see tables 3 and 4).

The accumulation of property undoubtedly encouraged persistence; all but two of the forty-eight persisters increased their assets in the $1860 \mathrm{~s}$. Several local merchants amassed

laborers, 1 shoemaker, 1 printer, 2 stone masons, 1 teamster, and 1 farmer, who owned land valued at less than two hundred dollars. 
TABLE 3

PERSISTENCE OF SIOUX CITY POPULATION, BY ETHNIC GROUP, 1860-1870

\begin{tabular}{lccc}
\hline $\begin{array}{l}\text { Ethnic } \\
\text { Group }\end{array}$ & $\begin{array}{c}\text { Gone } \\
\text { by } 1870\end{array}$ & $\begin{array}{c}\text { Remaining } \\
\text { in } 1870\end{array}$ & $\begin{array}{c}\text { Persistence } \\
\text { Rate }\end{array}$ \\
\hline U.S.-born & 61 & 35 & $36.5 \%$ \\
British & 5 & 2 & 28.6 \\
Irish & 7 & 6 & 46.2 \\
German & 11 & 4 & 26.7 \\
Other & 9 & 1 & 10.0 \\
$\quad$ Total & 93 & 48 & $34.0 \%$ \\
\hline
\end{tabular}

SOURCE: Manuscript U.S. Census, 1860.

exceptional wealth: shipper Daniel Hedges, steamboat captain James Sawyer, and German-born hardware dealer August Groninger each claimed fortunes of approximately one hundred thousand dollars. Moreover, nearly half of the persisters reported property valued at ten thousand dollars or more in 1870, while only five men of the total forty-eight spent the 1860 s caught in the lowest wealth rank (see table 5). Laborers William McElhany, a native of Virginia, Porter Pritchard from New York, and two or three others appear to have lived in continual poverty. Among those who remained in the community from 1860 to 1870 , however, the typical story was one of personal advancement. Three-quarters of the men in the lowest wealth category (\$0-999) in 1860 increased their property holdings in the ensuing decade, as did over half of those in the middle category $(\$ 1,000-9,999)$. Whereas 58 percent of these permanent residents possessed at least one thousand dollars in real or personal property in 1860, fully 85 percent of them owned that much by 1870 .

Such wealth was not common to all Sioux City men in 1870. The forty-eight long-term residents were a mere four percent of the total laboring population at the end of the decade, and their economic status set them apart from their neighbors. On the whole, the community's workers were a decidedly impoverished lot. Most of them, perhaps 1,000 of the 1,200 present in 1870, had come to Sioux City on the heels of railroad construction crews in 1868 and 1869. Their arrival made for a profound change in the community's socioeconomic character, 
TABLE 4

PERSISTENCE OF SIOUX CITY POPULATION, by Personal Wealth, $1860-1870$

\begin{tabular}{lccc}
\hline $\begin{array}{l}\text { Wealth } \\
\text { Group }\end{array}$ & $\begin{array}{c}\text { Gone } \\
\text { by } 1870\end{array}$ & $\begin{array}{c}\text { Remaining } \\
\text { in } 1870\end{array}$ & $\begin{array}{c}\text { Persistence } \\
\text { Rate }\end{array}$ \\
\hline$\$ 0-99$ & 18 & 6 & $25.0 \%$ \\
$100-999$ & 42 & 14 & 25.0 \\
$1,000-9,999$ & 29 & 24 & 45.3 \\
10,000 and up & 5 & 4 & 44.4 \\
\cline { 2 - 4 } Total & 94 & 48 & $33.8 \%$ \\
\hline
\end{tabular}

SOURCE: Manuscript U.S. Census, $1860,1870$.

most noticeably with respect to the distribution of wealth. Although average personal assets among them increased slightly, up to $\$ 2,470$ from $\$ 2,065$ ten years earlier, median wealth plunged nearly $\$ 600$ between 1860 and 1870 to a level just five dollars above penury. Seventy-five percent of Sioux City's workers in 1870 held less than one thousand dollars in real or personal property; more than 60 percent owned nothing at all (see table 6).

European immigrants as a group were poorer than U.S.born workers in 1870 . The immigrants, who by then made up almost half percent of all men aged twenty-one years and older, averaged $\$ 2,280$ less in personal assets than did men born in the United States. Ethnocultural means ranged from a high of $\$ 3,575$ for the U.S.-born to nothing for the community's 150 recently arrived Scandinavians. As in 1860, English and German immigrants diverged only slightly from the community mean in 1870, while personal assets among Sioux City's Irishmen averaged a low $\$ 852$. Precise figures on the property holdings of each ethnic group, which appear in table 1, indicate widening disparities in overall wealth.

More pronounced is the association between age and assets, for Sioux City's poorer men tended to be those just beginning their careers in 1870 (see table 7). Indeed, the major decline in average personal wealth between 1860 and 1870 occurred within the ranks of the labor force's youngest members. The mean value of wealth for men in their twenties was $\$ 1,566$ in 1860 ; in 1870 it was $\$ 508$. The change in average property holdings among men in their thirties was considerably 
TABLE 5

Changes in Wealth, Sioux City Persisters, 1860-1870

\begin{tabular}{|c|c|c|c|c|c|c|}
\hline \multirow[b]{3}{*}{ Wealth in 1860} & \multicolumn{6}{|c|}{ Wealth in 1870} \\
\hline & \multicolumn{2}{|c|}{$\$ 0-999$} & \multicolumn{2}{|c|}{$\$ 1,000-9,999$} & \multicolumn{2}{|c|}{$\$ 10,000$ and up } \\
\hline & $\mathrm{N}$ & $\%$ & $\mathrm{~N}$ & $\%$ & $\mathrm{~N}$ & $\%$ \\
\hline $\begin{array}{l}\$ 0-999 \\
\$ 1,000-9,999 \\
\$ 10,000 \text { and up }\end{array}$ & $\begin{array}{l}5 \\
2 \\
0\end{array}$ & $\begin{array}{r}25.0 \\
8.3 \\
0.0\end{array}$ & $\begin{array}{r}11 \\
8 \\
0\end{array}$ & $\begin{array}{r}55.0 \\
33.3 \\
0.0\end{array}$ & $\begin{array}{r}4 \\
14 \\
4\end{array}$ & $\begin{array}{r}20.0 \\
58.3 \\
100.0\end{array}$ \\
\hline Total & 7 & 14.6 & 19 & 39.6 & 22 & 45.8 \\
\hline
\end{tabular}

SOURCE: Manuscript U.S. Census, 1860, 1870.

NOTE: Calculation of wealth accumulation is based on property held in 1860 and 1870 . This technique ignores the possibility that one might win and lose a fortune one or more times in the course of a decade.

less, down about $\$ 100$ between 1860 and 1870 . The community's older workers, by contrast, did better than ever. Men aged forty and over in 1870 owned property with a mean value of $\$ 7,344$ in 1870 , an increase of nearly $\$ 3,000$ over the average assets of the oldest age group in 1860. The rise, of course, reflects the continued presence in Sioux City of such men as August Groninger, A. W. Hubbard, and several other highly successful frontier capitalists. Still, the high median wealth among these older men suggests that the increase in average assets bespeaks a general trend. During the 1860 s, occupational standing had become more strongly associated with age, which would explain the direct relationship between age and assets observed in 1870 . By that time there were proportionately fewer young men in prestigious and high-paying occupations than there had been before the Civil War.

Overall, however, the situation offered hope. Indigent newcomers to Sioux City who based their career expectations on the experiences of the community's old timers had reason to be optimistic in 1870. Pioneers who remained in Sioux City through the Civil War decade had done quite well for themselves, considering the stagnant condition of the local economy during most of the 1860s. Even workers at the bottom of the job scale in 1860, including such men as laborer John Hittle and liveryman Robert McElhaney, rose from the ranks of menial labor to positions of some respect and reward in the next ten years. McElhaney, who opened his own saddlery, and Hittle, 
TABLE 6

Changes in the Distribution of Wealth, Sioux City, 1860-1870

\begin{tabular}{lrrrrr}
\hline & \multicolumn{2}{c}{1860} & & \multicolumn{2}{c}{1870} \\
\cline { 2 - 3 } Wealth Group & $\mathrm{N}$ & $\%$ & & $\mathrm{~N}$ & $\%$ \\
\hline$\$ 0-99$ & 24 & 16.9 & & 272 & 64.0 \\
$\$ 100-999$ & 56 & 39.4 & & 45 & 10.6 \\
$\$ 1,000-9,999$ & 53 & 37.3 & & 79 & 18.6 \\
$\$ 10,000$ and up & 9 & 6.3 & & 29 & 6.8 \\
$\quad$ Total & 142 & 99.9 & & 425 & 100.0 \\
\hline
\end{tabular}

SOURCE: Manuscript U.S. Census, 1860, 1870.

who found work as a clerk in a store, increased their wealth holdings from virtually nothing in 1860 to properties valued at $\$ 33,000$ and $\$ 9,000$ respectively. Adam Falk, a barber who possessed just $\$ 225$ in 1860 , reported assets in excess of $\$ 5,000$ in 1870. While comparable success did not accrue to every Sioux Citian in the 1860 s, the good fortune of these individuals served to reassure their neighbors that the fledgling community supplied sufficient opportunity for self-improvement. Indeed, in 1870 the future looked brighter than it had since the land boom of the 1850s. Continued railroad construction, revived steamboat traffic, and expansion in all sectors of the local economy indicated fair chances of material advancement to all who would work.

RAILROAD CONSTRUCTION in northwest Iowa sparked Sioux City's rise as a regional entrepôt in the 1870s. Growing rural demand for urban goods and services encouraged Sioux City businessmen to enlarge plants and inventories and to increase payrolls. A nationwide business slump beginning in 1873 briefly curtailed railroad investment and rural settlement in the region but did not arrest commercial progress. Although Sioux Citians could not ignore the grim financial news reported from eastern cities in the mid-1870s, entrepreneurs such as James Booge and Ashbel Hubbard refused to stop boosting local enterprise. George Perkins's Sioux City Journal gives no hint that the community's business firms encountered serious difficulty in the period, and for once such silence may have been more than a matter of good public relations. Booge's striking success in expanding his meatpacking operation, which 
TABLE 7

Distribution OF WEALTH IN SiOUX CitY, ACCORDING TO AGE, 1860 AND 1870

\begin{tabular}{lccccc}
\hline & \multicolumn{2}{c}{1860} & & \multicolumn{2}{c}{1870} \\
\cline { 2 - 3 } \cline { 5 - 6 } Age & Number & Average Wealth & & Number & Average Wealth \\
\hline $20 \mathrm{~s}$ & 64 & $\$ 1,566$ & & 192 & $\$ 508$ \\
$30 \mathrm{~s}$ & 58 & 1,816 & & 135 & $\mathbf{9 1 2}$ \\
$40 \mathrm{~s}$ & 18 & 4,646 & & 98 & 7,344 \\
\cline { 2 - 3 } Total & 140 & $\$ 2,065$ & & 425 & $\$ 2,470$ \\
\hline
\end{tabular}

SOURCE: Manuscript U.S. Census, 1860, 1870.

owed a great deal to Hubbard's determined effort to keep railroad builders busy, benefited the city's entire economy. Unlike the panic of 1857, which nearly evacuated the community, the commercial ills of the 1870 s appear to have spared Sioux City businessmen any major embarrassment. New firms opened, old ones grew larger, and men continued to find work in local factories, shops, and warehouses. ${ }^{8}$

Sioux City's population nearly tripled during the 1870 s, rising to about 7,500 persons by 1880 . The growth of the labor force, from approximately 1,200 to 2,500 men, was less pronounced, which indicates the increased proportion of women and children resident in the community. ${ }^{9}$ Those men persisting through the decade represented about 20 percent of the total work force of 1870 . Despite the great economic changes brought by the railroad during the 1870 s, career patterns in Sioux City looked about the same as they had in the previous decade (see table 8 ). The men who had settled permanently in Sioux City by 1860 tended to be business proprietors and professionals-that is, workers already at the top of the job scale. The stable population of $1870-1880$ included propor-

8. William Shaw, comp., Sioux City Directory, 1871-1872 (n.p., n.d.); R. L. Polk, Iowa State Gazetteer and Business Directory for 1880-1881 (Detroit, 1880).

9. The sex ratio (the number of males per one hundred females) in Sioux City dropped from 131.0 in 1870 to 123.5 in 1873 and 106.6 in 1875. See Iowa Executive Council, Census of Iowa as Returned in the Year 1873 (Des Moines, 1874), 68; idem, Census of Iowa as Returned in the Year 1875 (Des Moines, 1875), 68; John A. T. Hull, comp., Historical and Comparative Census of the State of Iowa (Des Moines, 1883), 196-99. 
TABLE 8

Changes IN OCCuPATIONAL STATUS, SIOUX CITY PERSISTERS, 1860-1895

\begin{tabular}{|c|c|c|c|c|c|c|}
\hline \multirow{3}{*}{$\begin{array}{l}\text { Occupational Rank } \\
\text { at Beginning of } \\
\text { Decade }\end{array}$} & \multicolumn{6}{|c|}{ Occupational Change } \\
\hline & \multicolumn{2}{|c|}{ Better Job } & \multicolumn{2}{|c|}{ Same Job } & \multicolumn{2}{|c|}{ Wo:se Job } \\
\hline & $\mathrm{N}$ & $\%$ & $\mathrm{~N}$ & $\%$ & $\mathrm{~N}$ & $\%$ \\
\hline & \multicolumn{6}{|c|}{$1860-1870$} \\
\hline $\begin{array}{l}\text { Professionals and } \\
\text { businessmen }\end{array}$ & 0 & $0: 0$ & 24 & 88.9 & 3 & 11.1 \\
\hline $\begin{array}{l}\text { Clerks and craftsmen } \\
\text { Menial and day }\end{array}$ & 3 & 27.3 & 8 & 72.7 & 0 & 0.0 \\
\hline laborers & 5 & 55.6 & 4 & 44.4 & 0 & 0.0 \\
\hline \multirow[t]{2}{*}{ Total } & 8 & 17.0 & 36 & 76.6 & 3 & 6.4 \\
\hline & \multicolumn{6}{|c|}{$1870-1880$} \\
\hline $\begin{array}{l}\text { Professionals and } \\
\text { businessmen }\end{array}$ & 0 & 0.0 & 25 & 80.6 & 6 & 19.4 \\
\hline $\begin{array}{l}\text { Clerks and craftsmen } \\
\text { Menial and day }\end{array}$ & 3 & 10.3 & 25 & 86.2 & 1 & 3.4 \\
\hline laborers & 9 & 45.0 & 11 & 55.0 & 0 & 0.0 \\
\hline \multirow[t]{2}{*}{ Total } & 12 & 15.0 & 61 & 76.2 & 7 & 8.8 \\
\hline & \multicolumn{6}{|c|}{$1885-1895$} \\
\hline $\begin{array}{l}\text { Professionals and } \\
\text { businessmen }\end{array}$ & 0 & 0.0 & 21 & 75.0 & 7 & 25.0 \\
\hline $\begin{array}{l}\text { Clerks and craftsmen } \\
\text { Menial and day }\end{array}$ & 3 & 11.1 & 18 & 66.7 & 6 & 22.2 \\
\hline laborers & 12 & 38.7 & 19 & 61.3 & 0 & 0.0 \\
\hline Total & 15 & 17.4 & 58 & 67.4 & 13 & 15.1 \\
\hline
\end{tabular}

SOURCES: Manuscript U.S. Census, 1860, 1870, 1880; Manuscript Iowa State Census, $1885,1895$.

NOTE: Analysis of changes in job status requires the use of a scale of occupational prestige that remains stable over time. For this study, I have adapted a scale developed in 1974 by Theodore Hershberg and colleagues and now in general use among social historians. For a complete description of the Hershberg scale, see Theodore Hershberg, et al., "Occupation and Ethnicity in Five Nineteenth-Century Cities: A Collaborative Inquiry," Historical Methods Newsletter 7 (1974), 174-216. Professionals and businessmen include bankers, brokers, contractors, farmers, grocers, landlords, lawyers, managers, and merchants. Clerks and craftsmen include bakers, bookkeepers, bricklayers, carpenters, clerks, mechanics, millers, police, printers, and tailors. Menial and day laborers include expressmen, farmhands, gardeners, janitors, laborers, linemen, liverymen, railroad workers, teamsters, and warehouse workers. For a complete list of occupations, see my codebook, Five Towns in lowa, 1860-1895 (Iowa City, 1978). 
tionately fewer such top-ranked men and more clerks and craftsmen. Nonetheless, the percentage of men rising to higher occupational rank remained virtually unchanged from one decade to the next. About one in six local workers advanced occupationally in both ten-year periods, while the proportion slipping downward to a lower job rank increased only slightly from 6 percent in the 1860 s to 9 percent in the 1870 s. In each decade, three-quarters of the community's stable labor force experienced no apparent change in occupational status. ${ }^{10}$

Although age and ethnicity influenced the distribution of personal wealth in frontier Sioux City, neither factor proved decisive in shaping career patterns among men who lived there through the $1860 \mathrm{~s}$. Within this stable element of the work force, changes in occupational rank appear to have occurred randomly. There are no strong indications that national origin acted systematically to help or to hinder career advancement for men in any of the community's ${ }^{-}$ethnic groups. Some differences in the incidence of occupational mobility did appear among young workers in their twenties and thirties and those aged forty and older in 1860, but the small number of men included in the older age group discourages analysis of the distribution. By and large, Sioux Citians advanced according to individual merit-or we must presume so in the absence of evidence to the contrary.

The same generalization holds true for men employed in Sioux City in the 1870s, with a few minor qualifications. Again, age mattered little in terms of career advancement. Twenty-one percent of men aged forty and older enjoyed upward occupational mobility during the 1870 s, while 16 percent of those younger than forty improved their job status in

10. Estimates of the economic success of Sioux City's work force in the years 1870-1880 must be based on information concerning the men's occupational standing in 1880, for no record of personal assets exists for that year. Since job rank proved to be the strongest single indicator of individual wealth for workers in the period 1860-1870, cautious use of this surrogate in describing changes in socioeconomic status among the men of the 1870 s appears warranted. The relationship between wealth and job status in nineteenth-century populations is discussed at length in Stephan Thernstrom, The Other Bostonians: Poverty and Progress in the American Metropolis, 1880-1970 (Cambridge, MA, 1973), 289-302, and Theodore Hershberg, et al., "Occupation and Ethnicity in Five Nineteenth-Century Cities: A Collaborative Inquiry," Historical Methods Newsletter 7 (1974), 174-216. 
the course of the decade. Less than 10 percent of the men in each age group suffered appreciable downward mobility in the same period. Ethnic mobility patterns exhibited somewhat sharper contrasts, with Sioux City's Scandinavians doing better than the community norm and local Irishmen doing somewhat worse. Neither group contributed largely to the stable labor force of the 1870s; we are dealing here with just a few dozen men. Still, since low-ranked workers dominated both immigrant groups at the start of the decade, their contrasting experiences in the ensuing years suggest that Irish immigrants were burdened with lasting disabilities, perhaps as a result of the appalling circumstances of their emigration in the famine years of the late $1840 \mathrm{~s}$.

The Scandinavians who arrived in Sioux City after the Civil War exhibited an occupational distribution virtually identical to the Irish pattern in 1870, yet at least a few of these men worked their way up from the ranks of menial laborers in subsequent years. Swedish laborer John Anderson, for example, came to Sioux City in the late 1860s and worked as a common laborer for a year or two. By 1871 he had accumulated enough capital to open his own shoe repair shop opposite the railroad depot on Second Street. Anderson's trade catered to the city's working classes, which included many immigrants, crowded into the densely settled blocks just east of the central business district. Eventually Anderson needed three hired men to assist him in his repair business and in the manufacture of boots and shoes valued at more than three thousand dollars per year. Fellow immigrant Andrew Peterson organized a small plowmaking shop, which prospered as the rural population grew in Sioux City's immediate hinterland. Peterson never attempted to challenge the McCormick Company's dominance in the prairie implement market, but his shop drew a fair return from the hinterland trade and earned its proprietor a comfortable livelihood. ${ }^{11}$

No counterparts to these success stories appear among the community's Irish immigrants. The Irishmen tended to remain within a single job rank through the entire decade. More often

11. Manuscript U.S. Census, 1870, 1880; Manuscript Census of Manufactures, 1880; Shaw, Sioux City Directory, 1871-1872; Polk, Iowa State Gazetteer, 1880-1881, 497-501. 
TABLE 9

ETHNiC Distribution of Sioux City's MaLe Labor ForCE, $1860-1900$

\begin{tabular}{lcccccc}
\hline Ethnic Group & 1860 & 1870 & 1880 & 1885 & 1895 & 1900 \\
\hline U.S.-born & $68.1 \%$ & $51.5 \%$ & $57.1 \%$ & $64.2 \%$ & $60.4 \%$ & $64.6 \%$ \\
Canadian & 0.7 & 4.9 & 5.6 & 4.2 & 3.6 & 2.6 \\
British & 5.0 & 6.1 & 3.0 & 3.0 & 2.2 & 3.6 \\
Irish & 9.2 & 11.5 & 8.2 & 6.5 & 5.2 & 4.8 \\
German & 10.6 & 12.0 & 11.5 & 8.4 & 6.8 & 6.3 \\
Dutch & 0.0 & 0.0 & 0.6 & 0.0 & 0.6 & 1.0 \\
Scandinavian & 0.0 & 11.3 & 11.5 & 12.2 & 18.1 & 13.5 \\
Other & 6.4 & 2.6 & 2.4 & 1.5 & 3.0 & 3.4 \\
Total & $100.0 \%$ & $99.9 \%$ & $99.9 \%$ & $100.0 \%$ & $99.9 \%$ & $99.8 \%$ \\
Number in sample & 141 & 425 & 497 & 525 & 498 & 495 \\
\hline
\end{tabular}

SOURCES: Manuscript U.S. Census, 1860, 1870, 1880, 1900; Manuscript lowa State Census, 1885, 1895 .

than not, this meant menial labor on the wharves, at the depot, or in one of Sioux City's warehouses. There were also Irish clerks and craftsmen during the 1870 s, of course, so that local Irish immigrants need not have felt condemned to the ranks of the hardworking poor. Nonetheless, the infrequency of Irish advance is striking, and all the more so considering the Scandinavians' success in spite of the handicaps faced by European immigrants in the nineteenth century.

Swedes and Norwegians continued to arrive in Sioux City during the 1870s and 1880s, offsetting the departure of their compatriots who tarried only briefly in the Missouri River port before setting off for new homes elsewhere in the United States. German and Irish arrivals, on the other hand, diminished steadily after 1870 (see table 9). Whereas Scandinavians consistently made up at least 11 percent of the local labor force until after the turn of the century, the proportions of Irish and German workers fell below 10 percent of the total in the early 1880 s. Overall, a gradual decline in the percentage of foreignborn men living in Sioux City began in 1870 and accelerated after 1880, as the number of European immigrants shrank from about half to about 35 percent of all workers in the thirty years ending in 1900. 
PROFOUND CHANGES in Sioux City's economic base coincided with these alterations of its ethnic character. In the mid1880s, dollars earned in manufacturing surpassed wholesaling income for the first time as local processing industries emerged as Sioux City's leading employer. ${ }^{12}$ The commercial explosion ignited by such aggressive entrepreneurs as James Booge and Daniel Hedges created thousands of new jobs, many of them in construction, transportation, and clerical services as well as in manufacturing. Not only were there more jobs, but Sioux Citians also enjoyed greater variety of employment, as enlarged factories and storage facilities required more skilled technicians, foremen, and other supervisory personnel. The federal censuses of 1880 and 1900 point up these qualitative changes in local employment. In 1880 enumerators listed 104 occupational titles among Sioux City workers; in 1900 they noted 141. Most of the new titles represented various types of craft and clerical skills, areas of employment that traditionally provided avenues of upward mobility for menial laborers in Sioux City.

Other things being equal, the chances for individual advancement should have increased with the added job opportunities created by the growth of local business firms, but the industrial expansion of the $1880 \mathrm{~s}$ also initiated a number of technological changes-commonly involving mechanizationthat reduced the relative need for skilled workers and increased the proportion of operatives and other low-paid personnel in Sioux City's shops and factories. ${ }^{13}$ At the same time, the size of the labor force grew by approximately 1,500 men per year in the period 1885-1890. ${ }^{14}$ Thus, despite the increased number and variety of employment opportunities, competition for the best of the new positions proved as stiff as

12. Sioux City Jobbers and Manufacturers Association, Sioux City, Its Commerce and Manufactures (Sioux City, 1892).

13. Harold D. McCarty and C. W. Thompson, Meatpacking in Iowa (lowa City, 1933), 53-54.

14. I estimate that the size of the adult male labor force in Sioux City grew from about 6,500 in 1885 to about 13,000 in 1890 . These estimates are based on census counts for the two years. See Census of Iowa, 1885, 162; U.S. Census Office, Eleventh Census of the United States, 1890, Compendium, vol. 1 (Washington, DC, 1892), 819. 
ever. And finally, the decade of industrial expansion ended with a severe business crisis and a protracted depression that compounded the difficulties faced by ambitious Sioux City workers.

The pattern of individual careers in the period 18851895 shows the social consequences of the changing circumstances of local employment in Sioux City (see table 8). As in the 1860 s and 1870 s, nearly one-fifth (17.4 percent) of the community's stable labor force experienced significant advances in occupational status in the course of the decade. The most striking gains occurred among the unskilled workers of 1885: 38.7 percent of these men improved their job rank by 1895 , a slightly poorer showing than in the 1860 s and 1870 s. Clerical and skilled workers appear to have advanced between 1885 and 1895 about as frequently as they had previously, but they were more prone to downward mobility in the later period. Professionals and businessmen also experienced lowered status more often, suggesting that the myriad changes wrought on Sioux City's economy by industrialization made workers at all levels of the occupational hierarchy more vulnerable to periodic business crises such as that in 1893. Overall, the proportion of men in the stable work force maintaining consistent occupational rank through the years 1885-1895 shrank to 67.4 percent, down from about 75 percent in each of the two earlier decades.

Although this increased instability reflected the misfortune of a large number of Sioux Citians, two groups of workers did particularly well in the years of industrial expansion. Young men in their twenties demonstrated unusual ability to improve their economic status. For most of the young workers, occupational success meant a switch from menial labor to a skilled craft or clerical position, although there were a few cases of craftsmen who parlayed their skills into business proprietorships. William Gaylord, for example, worked as a common laborer in 1885; by 1890 he owned his own book and stationery store in the city's central business district. Carpenter-contractor John Swanson and carpenter-realtor Ed Semser had similar good fortune in the late $1880 \mathrm{~s}$. More typical of men in their age group was the experience of Jonathan Halvorson, a day laborer 
who found work as a carpenter in the local building boom during the first years of the $1890 \mathrm{ss}^{15}$

Somewhat surprisingly in light of the continual expansion of the city's manufacturing sector throughout the period, no discernible cases existed of individuals advancing from skilled blue-collar positions to low-level managerial occupations in this or any other age group. Moreover, the high incidence of upward mobility among young workers was offset to a certain extent by an unusually large number of men in their twenties who slipped downward in occupational rank during the decade. Thus while 32.1 percent of the youngest age group advanced, 17.9 percent declined in status. Again, the hallmark of the period was instability among all groups of Sioux City's employed citizenry. ${ }^{16}$

Similar qualifications apply to the employment pattern among Swedes and Norwegians, who continued their remarkable economic success in Sioux City through the early $1880 \mathrm{~s}$. For the first time since their arrival in the late 1860s, however, Scandinavian immigrants appear within the ranks of the downwardly mobile. The number was small, just 13.6 percent of the total, and hardly cancelled the impressive gains made by 36.4 percent of all Scandinavians in Sioux City's labor force. Neither national group held a monopoly on good fortune; occupational mobility occurred with about the same frequency among Swedes and Norwegians. As for Sioux City's other immigrant groups, career patterns in the years 1885-1895 looked much the same as they had since 1860 (see table 10). Irishmen demonstrated no proclivity for occupational advance, while other immigrants advanced and declined in proportions similar to those of the community's American-born workers.

THE CONTINUITY of career patterns among Sioux City workers throughout the late nineteenth century is not what one would expect in a community that witnessed such dramatic economic and demographic changes. Except for some consistent exceptionalism among Irish immigrants, Sioux City men

15. Manuscript Iowa Census, 1885; R. L. Polk, Sioux City Directory, 1890-1891 (Sioux City, 1890).

16. Manuscript lowa Census, 1885, 1895. 
TABLE 10

Changes in Occupational Status among Sioux City Persisters, ACCORDING TO ETHNIC GROUP, 1860-1895

\begin{tabular}{|c|c|c|c|c|c|c|}
\hline \multirow[b]{3}{*}{ Ethnic Group } & \multicolumn{6}{|c|}{ Occupational Change } \\
\hline & \multicolumn{2}{|c|}{ Better Job } & \multicolumn{2}{|c|}{ Same Job } & \multicolumn{2}{|c|}{ Worse Job } \\
\hline & $N$ & $\%$ & $\mathrm{~N}$ & $\%$ & $\mathrm{~N}$ & $\%$ \\
\hline & \multicolumn{6}{|c|}{$1860-1870$} \\
\hline $\begin{array}{l}\text { U.S.-born } \\
\text { Irish } \\
\text { German } \\
\text { Other }\end{array}$ & $\begin{array}{l}5 \\
2 \\
0 \\
1\end{array}$ & $\begin{array}{r}14.7 \\
33.3 \\
0.0 \\
33.3\end{array}$ & $\begin{array}{r}27 \\
4 \\
3 \\
2\end{array}$ & $\begin{array}{l}79.4 \\
66.7 \\
75.0 \\
66.7\end{array}$ & $\begin{array}{l}2 \\
0 \\
1 \\
0\end{array}$ & $\begin{array}{r}5.9 \\
0.0 \\
25: 0 \\
0.0\end{array}$ \\
\hline \multirow[t]{2}{*}{ Total } & 8 & 17.0 & 36 & 76.6 & 3 & 6.4 \\
\hline & \multicolumn{6}{|c|}{$1870-1880$} \\
\hline $\begin{array}{l}\text { U.S.-born } \\
\text { Irish } \\
\text { German } \\
\text { Scandinavian } \\
\text { Other }\end{array}$ & $\begin{array}{l}6 \\
0 \\
1 \\
2 \\
3\end{array}$ & $\begin{array}{c}13.3 \\
0.0 \\
7.1 \\
40.0 \\
37.5\end{array}$ & $\begin{array}{r}36 \\
6 \\
12 \\
3 \\
4\end{array}$ & $\begin{array}{l}80.0 \\
75.0 \\
85.7 \\
60.0 \\
50.0\end{array}$ & $\begin{array}{l}3 \\
2 \\
1 \\
0 \\
1\end{array}$ & $\begin{array}{r}6.7 \\
25.0 \\
7.1 \\
0.0 \\
12.5\end{array}$ \\
\hline \multirow[t]{2}{*}{ Total } & 12 & 15.0 & 61 & 76.2 & 7 & 8.8 \\
\hline & \multicolumn{6}{|c|}{$1885-1895$} \\
\hline $\begin{array}{l}\text { U.S.-born } \\
\text { Irish } \\
\text { German } \\
\text { Scandinavian } \\
\text { Other }\end{array}$ & $\begin{array}{l}5 \\
0 \\
1 \\
8 \\
1\end{array}$ & $\begin{array}{r}10.9 \\
0.0 \\
16.7 \\
36.4 \\
20.0\end{array}$ & $\begin{array}{r}35 \\
5 \\
4 \\
11 \\
3\end{array}$ & $\begin{array}{l}76.1 \\
71.4 \\
66.7 \\
50.0 \\
60.0\end{array}$ & $\begin{array}{l}6 \\
2 \\
1 \\
3 \\
1\end{array}$ & $\begin{array}{l}13.0 \\
28.6 \\
16.7 \\
13.6 \\
20.0\end{array}$ \\
\hline Total & 15 & 17.4 & 58 & 67.4 & 13 & 15.1 \\
\hline
\end{tabular}

SOURCES: Manuscript U.S. Census, 1860, 1870, 1880; Manuscript Iowa State Census, $1885,1895$.

experienced a modicum of occupational mobility regardless of age or national background. Furthermore, this general pattern appears not to have altered in response either to the commercial resurgence set off by the railroad's arrival in the late $1860 \mathrm{~s}$ or to the industrial boom of the $1880 \mathrm{~s}$. In each decade, approximately 17 percent of Sioux City's men advanced to a higher job rank. Downward mobility varied somewhat, from a low of 6.4 percent of the work force in the 1860 s to a high of 15.1 percent in the ten years after 1885, a decade that ended in severe economic depression. Employment data for the five years ending in 1900 support the conclusion that the increased incidence of status loss in the mid-1890s was a temporary effect of the busi- 
ness crisis rather than a long-term consequence of the industrial transformation of Sioux City's economy. The revival of trade and manufacturing in the late 1890 s not only reduced the frequency of status loss among Sioux City workers, but also provided opportunities sufficient to permit the occupational advancement of some 21.4 percent of the local labor force. ${ }^{17}$

The arrival of the Chicago meatpackers and the subsequent resuscitation of Sioux City's economy in the late 1890s brought changes to the organization of labor and management in key local firms. Those changes may have affected career chances for men in some occupational designations. If so, those organizational shifts would have been the first in the city's history to influence patterns of job advancement. From its earliest settlement, Sioux City attracted hopeful young men in search of opportunity. The city's shift from boat to rail transport brought thousands to the upper Missouri, as did the addition of industrial plants to the city's commercial enterprises in the 1880 s. Like the pioneers of the 1850 s, these newcomers came west looking for openings in life. Nineteenth-century Sioux City lived up to their expectations.

"THERE ARE DOZENS of thriving cities and towns in the region about Sioux City to whose growth limits cannot be set," wrote Sioux City Journal editor George Perkins in 1891. "The investor can hardly go amiss in them," he added, for "they cannot grow without aiding Sioux City's growth, and in the long run they will be helped by the prosperity of Sioux City." Other writers were less certain about the symbiosis. The historian of LeMars noted in 1891 that the spectacular rise of Sioux City, twenty-five miles to the south, had stymied his own town's development in recent years, and he expressed concern for the future of the smaller town. His comments echoed a growing sentiment among American journalists and social critics who argued that the same economic advances that spurred the rise. of great cities were gradually undermining the social founda-

17. Manuscript Iowa Census, 1895; Manuscript U.S. Census, 1900. 
tions of hundreds of provincial towns and villages in the United States. ${ }^{18}$

Popular magazine writer Henry Fletcher was one such alarmist. In 1895 Fletcher published an essay in The Forum, an influential American magazine, that described recent changes in the character of life in smaller communities throughout the Midwest. Innovations in transportation and communication had set these towns in a tailspin, he wrote, preempting their once vital role in American commerce. Railroad corporations and their industrial counterparts now dominated the national economy, leaving provincial businessmen with a shrinking volume of trade and little power to reverse their declining situation. What really bothered Fletcher, however, were the alleged demographic concomitants of these recent economic changes, particularly the departure of younger workers for the factories and offices of the nation's cities. No one could blame them for leaving, he admitted; only a fool would waste his talents in the "benumbing" social climate of a community apparently headed for commercial extinction. Populist that he was, Fletcher insisted that something be done to halt the emigration that robbed midwestern towns of "the young, the hopeful, the ambitious," leaving behind only "the superannuated, the feeble, the dull, [and] the stagnant rich." ${ }^{19}$

Fletcher's perception of transience among young workers was accurate, but he erred in seeing this as a small-town phenomenon. The migratory impulse affected American communities of all sizes. Indeed, Sioux City's rate of population turnover was higher than that of the towns and villages in its hinterland. ${ }^{20}$ But Fletcher's contention that the snialler commu-

18. Sioux City Journal, 1 January 1891; Warner, Woodbury and Plymouth, 597. The literature on this subject is vast. Summaries appear in Park Dixon Goist, From Main Street to State Street: Town, City, and Community in America (Port Washington, NY, 1977); Lewis Atherton, Main Street on the Middle Border (Bloomington, IN, 1954); Jean B. Quandt, From the Small Town to the Great Community: The Social Thought of Progressive Intellectuals (New Brunswick, NJ, 1970); and Page Smith, As a City Upon a Hill: The Town in American History (New York, 1966).

19. Henry J. Fletcher, "The Doom of the Small Town," The Forum 19 (April 1895), 214-23.

20. Silag, "Citizens and Strangers." 
nities could no longer offer their young men sufficient incentives to stay put is more problematic. Had hinterland towns such as LeMars or Cherokee ever offered chances for occupational mobility on a par with Sioux City? If so, had these opportunities declined over the years, or were the chances for personal advancement unaffected by the size of a community and its level of economic development? Of course, in absolute terms thriving business centers such as Sioux City had more jobs to offer men who sought to better their economic situations. Yet even at the height of its industrial expansion in the 1880s, the lion's share of these jobs involved menial labor. Assuming that Sioux City was at all typical, migration to the city did not assure success but only widened a man's field of opportunity. What happened thereafter was a product of talent, timing, and luck.

In the early 1880 s, years of rapid commercial expansion throughout northwest Iowa, Sioux Citians advanced with greater frequency than men in each of the smaller communities (see table 11). Yet the differences were no more than 10 percent. Orange City, a mere village of four hundred people in 1880 , appears to have offered opportunities for occupational mobility on a par with Sioux City, which numbered about 7,500 persons that year. Margins between Sioux City and the other hinterland towns are somewhat wider, perhaps wide enough to support claims as to the superiority of the urban center in providing paths of advancement for ambitious workers.

Yet what variations do exist among the towns' mobility rates might be explained in terms of the occupational structures of their respective stable labor forces. Towns with a large proportion of high-status workers show the lowest incidence of economic advancement. Men in such towns as LeMars and Cherokee were already concentrated at the top of the occupational hierarchy in 1880; they could go no higher. Proportionately more of the workers in Sioux City and Orange City fell into the scale's middle and lower ranks; thus they were more capable of advancement. Akron's tiny stable labor force provides slim ground for statistical interpretation, but even there the figures support the hypothesis that mobility rates had less to do with differences in the kind of economic opportunities available in each of the several towns than with the occupa- 


\section{TABLE 11}

OCCUPATIONAL CHANGES,

WORKERS IN FIVE NORTHWEST IOWA TOWNS, 1880-1885

\begin{tabular}{llll}
\hline Town & $\begin{array}{c}\text { Better } \\
\text { Job }\end{array}$ & $\begin{array}{c}\text { Same } \\
\text { Job }\end{array}$ & $\begin{array}{c}\text { Worse } \\
\text { Job }\end{array}$ \\
\hline Sioux City $(\mathrm{N}=141)$ & $23.4 \%$ & $65.2 \%$ & $11.3 \%$ \\
LeMars $(\mathrm{N}=184)$ & 15.2 & 74.4 & 10.3 \\
Cherokee $(\mathrm{N}=164)$ & 13.4 & 73.9 & 12.8 \\
Orange City $(\mathrm{N}=42)$ & 21.4 & 76.2 & 2.4 \\
Akron $(\mathrm{N}=18)$ & 16.7 & 72.2 & 11.1 \\
\hline
\end{tabular}

SourCES: Manuscript U.S. Census, 1880; Manuscript Iowa State Census, 1885.

tional configuration of that part of their respective work forces resident in the communities for the full five-year period. ${ }^{21}$ With regard to Henry Fletcher's claims, it appears that commercial activity in all of the region's communities during the early 1880 s generated new job openings in sufficient supply to satisfy ambitious workers regardless of their place of residence. In this brief period, at least, the specific character of local economies had little effect on the chances that a man would improve his social status in the course of his working life.

The evidence pertaining to occupational mobility in the next decade, 1885-1895, is more suggestive of intercommunity differences (see table 12). First, the relationship between the frequency of individual advancement and the occupational distribution of stable labor forces is still apparent, although less striking than in earlier years. Second, rates of upward mobility among low-status workers in 1885 were similar in Sioux City, LeMars, and Cherokee ( 35 to 39 percent), while in Orange City the incidence of blue-collar advancement was somewhat lower (26.7 percent). Villages such as Kingsley and Akron had so few menial laborers that meaningful comparisons between them and the larger towns would be inappropriate. However, none of the smallest towns' low-status workers in 1885 managed to climb higher on the local economic scale in the ensuing decade.

21. Stephan Thernstrom discusses the relationship between community size and rate of occupational mobility with respect to mobility studies completed as of 1972 in The Other Bostonians, 232-41. See also Robert Doherty, Society and Power: Five New England Towns, 1800-1860 (Amherst, 1977), 70-81. 
TABLE 12

Occupational Change in Seven Northwest IOWa Communities, 1885-1895

\begin{tabular}{|c|c|c|c|}
\hline Town & $\begin{array}{l}\text { Better } \\
\text { Job }\end{array}$ & $\begin{array}{l}\text { Same } \\
\text { Job }\end{array}$ & $\begin{array}{c}\text { Worse } \\
\text { Job }\end{array}$ \\
\hline $\begin{array}{l}\text { Sioux City } \\
\text { High }(\mathrm{N}=28) \\
\text { Middle }(\mathrm{N}=27) \\
\text { Low }(\mathrm{N}=31)\end{array}$ & $\begin{array}{l}-\overline{11.1 \%} \\
38.7\end{array}$ & $\begin{array}{l}75.0 \% \\
66.7 \\
61.3\end{array}$ & $\begin{array}{l}25.0 \% \\
22.2 \\
-\end{array}$ \\
\hline Total $(\mathrm{N}=86)$ & 17.4 & 67.4 & 15.1 \\
\hline $\begin{array}{l}\text { LeMars } \\
\quad \text { High }(N=57) \\
\text { Middle }(N=56) \\
\text { Low }(N=23)\end{array}$ & $\begin{array}{l}- \\
12.5 \\
39.1\end{array}$ & $\begin{array}{l}78.9 \\
82.1 \\
60.9 \\
\end{array}$ & $\begin{array}{r}21.1 \\
5.4 \\
-\end{array}$ \\
\hline Total $(N=136)$ & 11.8 & 77.2 & 11.0 \\
\hline $\begin{array}{l}\text { Cherokee } \\
\text { High. }(N=68) \\
\text { Middle }(N=63) \\
\text { Low }(N=57)\end{array}$ & $\begin{array}{l}- \\
23.8 \\
35.1\end{array}$ & $\begin{array}{l}83.8 \\
71.4 \\
64.9\end{array}$ & $\begin{array}{c}16.2 \\
4.8 \\
-\end{array}$ \\
\hline Total $(\mathrm{N}=188)$ & 18.6 & 73.9 & 7.4 \\
\hline $\begin{array}{l}\text { Orange City } \\
\text { High }(\mathrm{N}=23) \\
\text { Middle }(\mathrm{N}=31) \\
\text { Low }(\mathrm{N}=15)\end{array}$ & $\begin{array}{l}- \\
38.7 \\
26.7\end{array}$ & $\begin{array}{l}87.0 \\
58.1 \\
73.3\end{array}$ & $\begin{array}{r}13.0 \\
3.2 \\
-\end{array}$ \\
\hline Total $(N=69)$ & 23.2 & 71.0 & 5.8 \\
\hline $\begin{array}{l}\text { Akron } \\
\text { High }(N=9) \\
\text { Middle }(N=7) \\
\text { Low }(N=5)\end{array}$ & $\begin{array}{c}- \\
14.3 \\
0.0\end{array}$ & $\begin{array}{r}44.4 \\
42.8 \\
100.0\end{array}$ & $\begin{array}{c}55.6 \\
42.8 \\
-\end{array}$ \\
\hline Total $(\mathrm{N}=21)$ & 4.8 & 57.1 & 38.1 \\
\hline $\begin{array}{l}\text { Kingsley } \\
\quad \text { High }(N=20) \\
\text { Middle }(N=16) \\
\text { Low }(N=1)\end{array}$ & $\begin{array}{l}- \\
12.5 \% \\
0.0\end{array}$ & $\begin{array}{l}80.0 \% \\
81.2 \\
100.0\end{array}$ & $\begin{array}{l}20.0 \% \\
6.2 \\
- \\
\end{array}$ \\
\hline Total $(\mathrm{N}=37)$ & 5.4 & 81.1 & 13.5 \\
\hline $\begin{array}{l}\text { Lincoln Township } \\
\text { High }(\mathrm{N}=40) \\
\text { Middle }(\mathrm{N}=1) \\
\text { Low }(\mathrm{N}=3)\end{array}$ & $\begin{array}{l}- \\
100.0 \\
100.0\end{array}$ & $\begin{array}{r}100.0 \\
0.0 \\
0.0\end{array}$ & $\begin{array}{l}0.0 \\
0.0 \\
-\end{array}$ \\
\hline Total $(\mathrm{N}=44)$ & 9.1 & 90.9 & 0.0 \\
\hline
\end{tabular}

SOURCE: Manuscript Iowa State Census of Population, 1885, 1895.

Note: High = professionals and businessmen, Middle = clerks and craftsmen, Low = menial and day laborers. 
Of the seven communities, in fact, Akron and Kingsley display the lowest incidence of overall occupational mobility, just 4.8 and 5.4 percent of their respective labor forces. Even the workers of agricultural Lincoln Township, an area in Plymouth County with no urban settlement of any size within its boundaries, did better than the men of the rural villages. All of this would suggest that in northwest Iowa only the smallest urban communities limited economic opportunities. ${ }^{22}$

Finally, evidence for the decade ending in 1895 reveals no wholesale changes wrought by the business crisis of 1893 on rates of downward mobility in the towns of northwest Iowa. Aside from Sioux City, only Akron shows a marked difference in the frequency of status loss among local workers between the two periods. Since comparably sized Kingsley did not share in this misfortune, it seems likely that Akron's bad luck was a local peculiarity rather than a widespread phenomenon affecting country villages in general. Elsewhere in the region, rates of status loss point to no apparent trends or generalizations, except that workers in Sioux City suffered the consequences of the depression more severely than did men in nearly every one of the smaller towns. With the return of prosperity in the late $1890 \mathrm{~s}$, the incidence of downward mobility declined in most communities, and in no town did the rate of status loss exceed 10 percent.

SIOUX CITY'S PIONEERS provided a more accurate characterization of life and labor in northwest Iowa in the nineteenth century than did journalist Henry Fletcher. Individuals attained high rates of success in communities of varying sizes in the region in all periods except during the years of economic depression in the 1890s. Even then, only the smallest communities bore the marks of the social stagnation identified in Fletcher's famous article. Otherwise, the story reads as if it were written by Constant R. Marks himself. Sioux City's pioneers, their successors, and their counterparts in the railroad towns and market centers of the rural hinterland enjoyed the personal

22. This corroborates the findings of Doherty, Society and Power, 56-69. 
rewards of regional economic growth throughout the nineteenth century.

Certainly there were plenty of individuals who failedcases of arrested mobility, socioeconomic decline, and frustrated ambition. But by and large, men working in northwest Iowa during the decades of settlement and early development had reason to feel confident that their hard work would be rewarded. The land was fertile, the towns were growing, and the social order was perhaps as open as any in American history. Personal fortunes may have been harder to come by later in the period than in the frontier years-and maybe not, since industrialization after the railroad's arrival created new opportunities for wealth in manufacturing as well as in commerce.

Throughout the period 1860-1900, Sioux City and its hinterland offered its working men "an opening in life," and many took advantage of it. Their individual successes-and, perhaps more importantly, their confidence that success would eventually be theirs-influenced the way the men of the region perceived society and their place in it. Optimism about the possibility of success produced a strong cultural consensus that played down socioeconomic differences within the community in the nineteenth century. In addition, the material achievement of large numbers of the European immigrants who settled in Sioux City and its hinterland reinforced the belief in opportunities open to all. A concomitant belief in the social benefits of commercial progress discouraged political opposition to business leadership in the communities of the region. Who would stand in the way of the forces of personal ambition and achievement?

This confidence made good sense from the Civil War era until just before the turn of the century. In the 1890s, however, a series of natural and financial calamities left Sioux Citians wondering whether the doors of opportunity had closed. Recent historical studies suggest that opportunities were indeed closing, or at least narrowing, by $1900 .^{23}$ The political conse-

23. See "Perspectives on Sioux City," a special issue of the Annals of Iowa 50 (Fall 1989/Winter 1990) for discussions of the changing perceptions of local opportunity-social and economic-in Sioux City in the late nineteenth and early twentieth centuries. 
quences of this changing situation included the rise of something approaching class-conscious politics in Sioux City; other forms of antiestablishment political activity would later appear in other parts of the region as well. Until then, however, the principle that hard work guaranteed material reward was secure in the minds of people in urban and rural areas alike. Not just an article of faith, as it had been for the region's pioneers, it was now a common experience for the men of northwest lowa. 
Copyright of Annals of Iowa is the property of State of Iowa, by \& through the State Historical Society of Iowa and its content may not be copied or emailed to multiple sites or posted to a listserv without the copyright holder's express written permission. However, users may print, download, or email articles for individual use. 